\title{
Does bivalve mucus favour the growth of their main food source, microalgae?
}

\author{
Bruno COGNIE, Laurent BARILLÉ*
}

Laboratoire de biologie marine, ISOMer, faculté des sciences et des techniques, 2, rue de la Houssinière, BP 92208, 44322 Nantes cedex 3, Francc; barille@svt.univ-nantes.fr

(Received 10 August 1998, revised 6 November 1998, accepted 30 November 1998)

\begin{abstract}
Bivalves, by releasing inorganic nutrients, can stimulate the growth of the primary producers on which they feed. Dissolved excretion and mineralization of biodeposits (pseudofaeces and faeces), two indirect processes related to their feeding activity, have already been identified. This study investigated whether microalgal growth is also dependent on the mucus secreted by bivalves and rejected with their biodeposits. An experimental study based on algal growth tests was conducted to determine whether the mucus coating the pseudofaeces and faeces of the oyster Crassostrea gigas (Thunberg) could stimulate the growth of nine marine microalgae: a Prasinophyceae [Tetraselmis suecica (Butcher)] and eight Diatomophyceae [Amphora sp. (Ehrenberg), Chaetoceros sp. (Ehrenberg), Entomoneis alata (Ehrenberg), Haslea ostrearia (Simonsen), Nitzschia acicularis (Wm Smith), N. closterium (Wm Smith), N. gandersheimiensis (Krasske) and Skeletonema costatum (Cleve)]. Oysters were fed only inorganic particles at a concentration well above the threshold of pseudofaeces production. A fraction of pseudofaeces and faeces was then inoculated into glass tubes containing a single algal species. Algal growth tests showed that mucus stimulated the growth of four of the nine species studied: Chaetoceros sp., $H$. ostrearia, $N$. gandersheimiensis and $T$. suecica. The strongest responses were observed with $H$. ostrearia and Chaetoceros sp., for which mean algal biomass was significantly higher with mucus originating from pseudofaeces than faeces. Monitoring of the release of dissolved components from mucus showed significant enrichment in inorganic phosporus. The use of an antibiotic treatment suggested that this dissolved component is released by simple solubilization rather than by bacterial breakdown. (O) Elsevier, Paris / Ifremer / CNRS / IRD
\end{abstract}

\section{bivalve / microalgae / mucus / faeces / pseudofaeces}

Résumé - Le mucus des bivalves favorise-t-il la croissance de leur principale source de nourriture, les microalgues? Les bivalves, en relarguant des sels nutritifs, peuvent stimuler la croissance des microalgues dont ils se nourrissent. L'excrétion dissoute et la minéralisation de leurs biodépôts (pseudofêces et fèces), deux processus liés à leur alimentation, ont déjà été identifiés. Dans ce travail, il est envișagé que la croissance des microalgues puisse être aussi stimulée par le mucus sécrété par les bivalves et rejeté dans leurs biodépôts. Une étude expérimentale fondée sur des tests de croissance algale a été réalisée afin de déterminer si le mucus enrobant les pseudofèces et les fêces de l'huître Crassostrea gigas (Thunberg) pouvait stimuler la croissance de neuf microalgues marines : une Prasinophycée [Tetraselmis suecica (Butcher)] et huit Diatomophycées [Amphora sp. (Ehrenberg), Chaetoceros sp. (Ehrenberg), Entomoneis alata (Ehrenberg), Haslea ostrearia (Simonsen), Nitzschia acicularis (Wm Smith), N. closterium (Wm Smith), N. gandersheimiensis (Krasske) et Skeletonema costatum (Cleve)]. Les huîtres sont alimentées uniquement par des particules inorganiques à une concentration très supérieure au seuil de production des pseudofèces. Une fraction des pseudofèces et feces est alors inoculée dans des tubes en verre contenant une espèce de microalgue. Les tests de croissance algale montrent que le mucus stimule la croissance de quatre des neuf espèces étudiées : Chaetoceros sp., H. ostrearia, $N$. gandersheimiensis et $T$. suecica. Les réponses les plus fortes sont obtenues avec Chaetoceros sp. et $H$. ostrearia, pour lesquelles la biomasse algale moyenne est significativement plus importante avec le mucus provenant des pseudofeces qu'avec celui provenant

* Correspondence and reprints 
des fèces. Un suivi du relargage de composés dissous par le mucus montre un enrichissement significatif en phosphore inorganique. Un traitement antibiotique suggère que ce composé dissous est libéré par simple solubilisation du mucus plutôt que par dégradation bactérienne. (C) Elsevier, Paris / Ifremer / CNRS / IRD

\section{bivalve / microphyte / mucus / fèces / pseudofèces}

\section{INTRODUCTION}

The impact of filter-feeding bivalves on microphyte biomass can be considered essentially as an antagonistic action resulting from a direct process (depletion by grazing) and an indirect effect (stimulation through nutrient regeneration). During consumption, bivalves remove significant amounts of phytoplanktonic cells $[2,3,15$, $25,40]$. However, large populations of bivalves such as oysters or mussels may stimulate primary production of microalgae by releasing inorganic nutrients originating from the dissolved excretion of the animals $[2,3,18,26$, $34,52,55,59]$ and/or mineralization of bivalve particulate excretion, pseudofaeces and faeces [25, 45, 54]. Moreover, these two feedback mechanisms may have a qualitative impact on the microphyte community. The influence of dissolved excretion on the selective development of phytoplanktonic and phytobenthic species has been demonstrated experimentally [58]. Similarly, the nutrients regenerated by mineralization of pseudofaeces and faeces could affect the structure of the microalgal community by changing nutrient ratios [45, 54].

The present study considered a third mechanism (in addition to dissolved excretion and mineralization of pseudofaeces and faeces) by which suspension-feeding bivalves may favour the development of the primary producers on which they prey and induce modifications in specific composition within a microalgal community. Biodeposits (both pseudofaeces and faeces), produced in huge amounts by bivalves in turbid environments [5, 31], are coated with mucus [30]. It is possible that this mucus rejected with the biodeposits may stimulate microalgal growth. The mucus produced by marine gastropods is known to provide nutrients for the microalgae upon which they feed $[16,17,23]$. However, except for the brief early observations of Ranson [47], the possible role played by bivalve mucus has not been studied.

In filter-feeding bivalves, mucus is a secretion produced at all stages of feeding, essentially for particle processing, cleaning of epithelia and protection against digestive enzyme $[8,11,35,39,60]$. Mucocytes present in the gill and labial palps are involved in pseudofaeces production
$[6,7]$, and large amounts of mucus are rejected with pseudofaeces [33]. After digestion, a fraction of the particles, mixed with metabolic faecal losses (digestive enzymes and fragments of digestive epithelium) and compacted with the different mucuses secreted by the digestive system $[8,10,41]$, are excreted in the faeces. In bivalves, mucus consists of protein-polysaccharide complexes commonly termed mucopolysaccharides, that have been classified according to their degree of acidity, from neutral to acid [9]. However, there is no information in the literature about the detailed structure of bivalve mucus. Therefore, we attempted to differentiate the mucus of pseudofaeces from that of faeces on the basis of their distinct roles in feeding processes.

Algal growth tests were used to determine whether the mucus of pseudofaeces and faeces produced by the oyster Crassostrea gigas can stimulate microalgal growth and have an impact on specific diversity. Eight Diatomophyceae and one Prasinophyceae were chosen to cover different ecological types and provide a broad size range. The release of dissolved components from mucus was also investigated. A distinction was made between the dissolution of mucus and release due to bacterial action.

\section{MATERIALS AND METHODS}

Japanese oysters (Crassostrea gigas) 6 to $10 \mathrm{~cm}$ in length were collected on rocks in the intertidal area of Bourgneuf Bay (France) $\left(46-47^{\circ} \mathrm{N}, 1-2^{\circ} \mathrm{W}\right)$, cleaned of epibionts and kept in filtered (Millipore $0.45 \mu \mathrm{m}$ ), oxygenated sea water for one week before experimentation. This one-week interval provided an acclimation period and avoided any contamination of faeces by algae present in the oyster gut.

The experimental system was based on the flow-through design of Vahl [57] and Palmer and Williams [42]. A $25 \mathrm{~L}$ header tank containing filtered sea water was connected to four individual $2 \mathrm{~L}$ trays each containing a single oyster. Baffles in each tray limited turbulence which could have resuspended the biodeposits. The system was set for an average flow of $5 \mathrm{~L} \mathrm{~h}^{-1}$ per tray. The sea water 
was oxygenated and the temperature thermoregulated at $20{ }^{\circ} \mathrm{C}$. Kaolinite was added to sea water in the acclimation tank containing the oysters and in the header tank in which vigourous aeration ensured mixing. The total particulate matter concentration obtained by the addition of kaolinite $600 \mathrm{mg} \mathrm{L}^{-1}$, which was similar to that frequently found during spring tides on the intertidal mud flat of Bourgneuf Bay [29], provided considerable production of biodeposits.

\subsection{Biodeposit sampling and analysis}

Oysters producing biodeposits in the acclimation tank were placed in individual trays from which pseudofaeces and faeces were collected directly. All pseudofaeces and faeces produced by the different oysters were collected in two different flasks, one for pseudofaeces and the other for faeces. A fraction of each was subsequently inoculated into glass tubes for algal growth tests. A similar amount of particulate material was collected in each flask. Pseudofaeces consisted only of kaolinite coated with mucus, whereas faeces were composed of kaolinite, mucus and digestive secretions. A control was established using a sample of sea water collected from the animal environment and mixed in a third flask with a quantity of kaolinite equivalent to that in the flasks containing biodeposits. Samples were vortexed to break up the biodeposits and homogenize the sample. With the loss-on-ignition method, a fraction of the samples was used to determine the organic matter corresponding to the amount of mucus added to the microalgae. As the biodeposits were composed of mucus and kaolinite, the particulate organic matter concentration was corrected for the loss of kaolinite structural water during calcination [19]. The remaining fraction of each flask was used to study the production of dissolved components from the mucus of biodeposits.

\subsection{Algal growth tests}

Growth tests were performed using cotton wool-plugged glass tubes $20 \mathrm{~cm}$ long and $2 \mathrm{~cm}$ in diameter. A $2 \mathrm{~mL}$ aliquot of each sample (pseudofaeces, faeces, control) was inoculated into a glass tube filled with $22 \mathrm{~mL}$ of ES $1 / 3$ medium ([46], as modified by Robert [50]) seeded beforehand with $1 \mathrm{~mL}$ of algal culture. Nine species of marine microphytes were chosen to cover a wide size range and different ecological types (benthic, pelagic and tychopelagic). Among these nine species isolated from oyster fattening ponds near Bourgneuf Bay, eight were Diatomophyceae and the other a Prasinophyceae (table I).

For each species, glass tubes were used in quadruplicate for pseudofaeces, faeces and the control. The tubes were placed in a culture room (temperature: $14^{\circ} \mathrm{C}$, light/dark: 14/10 hours, light intensity: $100 \mu \varepsilon \mathrm{m}^{-2} \mathrm{~s}^{-1}$ ). Algal growth was monitored with a spectrophotometer at $665 \mathrm{~nm}$. The cells of the three series (pseudofaeces, faeces, control) were counted once one of them reached the stationary phase, i.e. maximal algal biomass. Cell counts were done on haematometric cells, and empty frustules were not taken into account.

\subsection{Study of the production of dissolved components from mucus of biodeposits}

An aliquot of a sample (pseudofaeces, faeces, or control) was injected into 48 glass tubes containing Provasoli's ES $1 / 3$ medium in order to monitor the production of dissolved components from the mucus of biodeposits.

Table I. Main characteristics of the nine microalgal species. $\mathrm{L}=$ valve length, $\mathrm{l}=$ valve width, $\mathrm{D}=$ valve diameter.

\begin{tabular}{lllll}
\hline Species & \multicolumn{1}{c}{ Class } & Order & \multicolumn{1}{c}{ Size } & Ecological type \\
\hline Amphora sp. & Diatomophyceae & Pennatae & $\mathrm{L}: 10 \mu \mathrm{m}, 1: 8 \mu \mathrm{m}$ & benthic \\
Chaetoceros sp. & Diatomophyceae & Centricae & $\mathrm{D}: 4 \mu \mathrm{m}$ & pelagic \\
Entomoneis alata & Diatomophyceae & Pennatae & $\mathrm{L}: 60 \mu \mathrm{m}, 1: 20 \mu \mathrm{m}$ & benthic \\
Haslea ostrearia & Diatomophyceae & Pennatae & $\mathrm{L}: 90 \mu \mathrm{m}, 1: 12 \mu \mathrm{m}$ & tychopelagic \\
Nitzschia acicularis & Diatomophyceae & Pennatae & $\mathrm{L}: 65 \mu \mathrm{m}, 1: 10 \mu \mathrm{m}$ & pelagic \\
Nitzschia closterium & Diatomophyceae & Pennatae & $\mathrm{L}: 40 \mu \mathrm{m}, 1: 5 \mu \mathrm{m}$ & tychopelagic \\
Nitzschia gandersheimiensis & Diatomophyceae & Pennatae & $\mathrm{L}: 40 \mu \mathrm{m}, 1: 13 \mu \mathrm{m}$ & benthic \\
Skeletonema costatum & Diatomophyceat & Centricae & $\mathrm{L}: 10 \mu \mathrm{m}, 1: 6 \mu \mathrm{m}$ & pelagic \\
Tetraselmis suecica & Prasinophyceae & Chlorodendrale & $\mathrm{L}: 20 \mu \mathrm{m}, 1: 13 \mu \mathrm{m}$ & pelagic \\
\hline
\end{tabular}



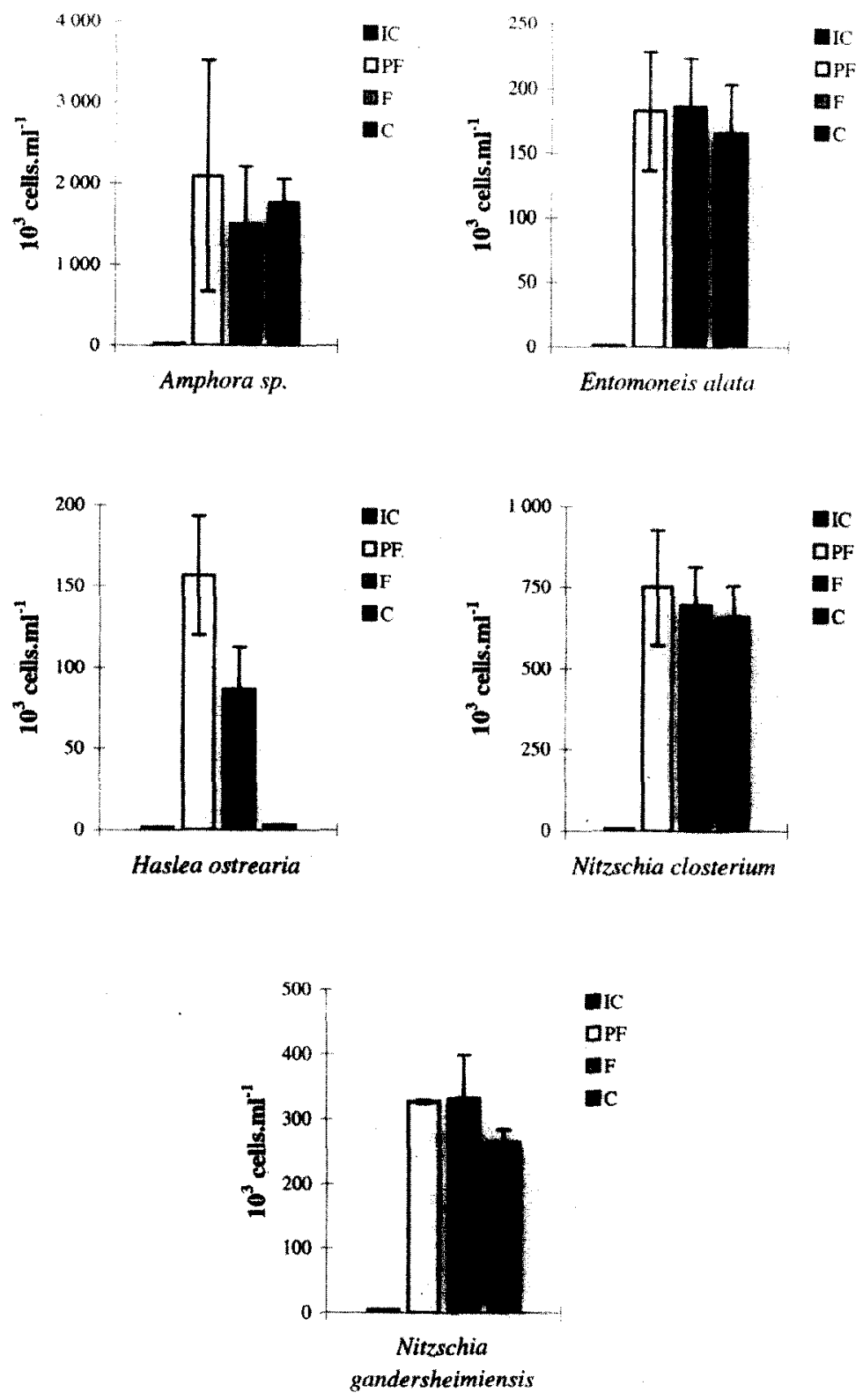

Figure 1. Mean algal biomass reached with benthic and tychopelagic microalgae in bioassays enriched with mucus coating pseudofaeces and faeces of Crassostrea gigas.

IC $=$ initial concentration of cells, $\mathrm{PF}=$ pseudofaeces, $\mathrm{F}=$ faeces, $\mathrm{C}=\mathrm{control}$. Means are shown with their $95 \%$ confidence interval (number of measurements $=4$ ).

ES $1 / 3$ medium was used to mimic the conditions of the algal growth tests. An antibiotic solution (10 000 units of penicillin, $10 \mathrm{mg}$ streptomycin and $25 \mu \mathrm{g}$ amphotericin $B$ per $\mathrm{mL}$ ) was added in 24 tubes to study abiotic fluxes. The 48 lubes were placed in a culture room (temperature: $14{ }^{\circ} \mathrm{C}$, light/dark: $14 / 10$ hours, light intensity: $100 \mu \varepsilon \mathrm{m}^{-2} \mathrm{~s}^{-1}$ ). As most algal growth tests were counted on the sixth day, analysis was performed after six days of incubation. A fraction of each sample was analysed with a continuous flow auto-analyser (Skalar), and the amounts of $\mathrm{NO}_{2}^{-}, \mathrm{NO}_{3}^{-}, \mathrm{NH}_{4}^{+}, \mathrm{PO}_{4}^{3-}, \mathrm{SiO}_{3}^{-}$, dissolved organic nitrogen, dissolved organic phosphorus, dissolved total nitrogen and dissolved total phosphorus were estimated using standard methods described in Moreau [38]. Carbohydrates were also quantified using the standard method of Dubois et al. [27]. However, only the fraction below $3000 \mathrm{Da}$, which may contain small polysaccharides directly usable by microalgae, was analysed. Each sample was therefore filtered with an ultrafilter (Diaflo Amicon, 3000 Da regenerated cellulose membrane). 

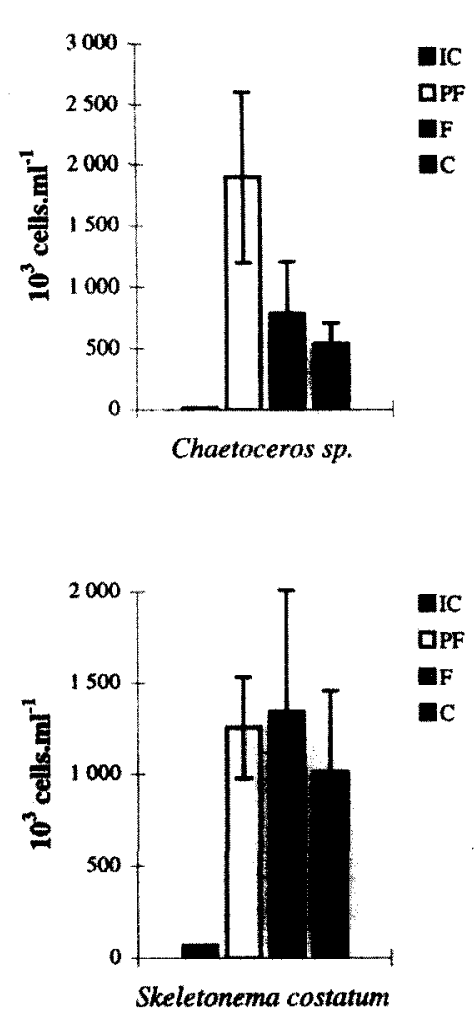
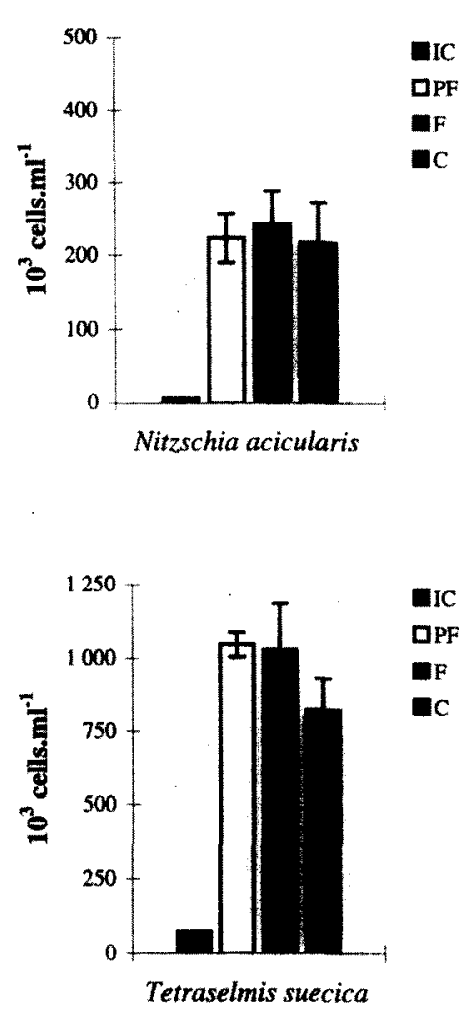

Figure 2. Mean algal biomass reached with pelagic microalgae in bioassays enriched with mucus coating pseudofaeces and faeces of Crassostrea gigas. $\mathrm{IC}=$ initial concentration of cells, $\mathrm{PF}=$ pseudofaeces, $\mathrm{F}=$ faeces, $\mathrm{C}=$ control. Means are shown with their $95 \%$ confidence interval (number of measurements $=4$ ).

\subsection{Statistical analysis}

Data were compared using t-tests and one-way analysis of variance (ANOVA) after transformation by square root. SNK a posteriori tests were run with ANOVA data.

\section{RESULTS}

The mucus rejected with pseudofaeces and faeces of the oyster $C$. gigas, which was subjected to a high inorganic particulate matter concentration, was the main source of organic matter found in these biodeposits, representing $8.3 \%$ and $9.2 \%$ per $\mathrm{mg}$ of dry weight of pseudofaeces and faeces respectively. The amount of organic matter from the mucus added into each tube for algal growth tests represented $0.2 \mathrm{mg}$ for pseudofaeces and faeces.

The nine algal species showed growth in the three series of tubes, except for the $H$. ostrearia control which developed very little (figures 1,2 ). The final algal biomasses were all quite different from initial ones. The mean number of cells per $\mathrm{mL}$, counted at the end of experimental growth, was lower in controls than the mean algal bio- mass obtained with pseudofaeces and faeces for eight out of nine microalgae. Only Amphora sp. grew less than the control with mucus and secretions from faeces. However, statistical comparison of mean algal biomasses indicated that for five microalgae (Amphora sp., E. alata, N. acicularis, $N$. closterium and S. costatum) there was no significant difference between controls and tubes seeded with the mucus and biodeposit secretions (ANOVA, $\mathrm{P}>0.05$; table II). For the other four microalgae $[H$. ostrearia (figure 1), N. gandersheimiensis (figure 1), Chaetoceros sp. (figure 2) and T. suecica (figure 2)], measured growth was significantly greater when experimental tubes were enriched with mucus coating biodeposits (ANOVA, $\mathrm{P} \leq$ 0.01 ; table II). With $N$. gandersheimiensis and T. suecica, an a posteriori test of means showed no significant difference between mucus enrichments according to the type of biodeposit (SNK test, $\mathrm{P}>0.05$; table II). The greatest differences were obtained with $H$. ostrearia and Chaetoceros $\mathrm{sp}$. for which growth was significantly greater with pseudofaeces than faeces (SNK test, $\mathrm{P} \leq 0.001$; table II).

The first phase of results indicated that mucus stimulated the growth of four microalgae. Subsequently, dissolved components from the mucus of pseudofaeces, together 
Table II. One way analysis of variance and SNK a posteriori tests of the means of the number of cells per mL counted in the experimental tubes inoculated with pseudofaeces or faeces and in controls.

$\mathrm{PF}=$ pseudofaeces, $\mathrm{F}=$ faeces, $\mathrm{C}=$ control, N.S. (Not Significant $)=0.05<\mathrm{P}, * *=0.001<\mathrm{P} \leq 0.01, * * *=\mathrm{P} \leq 0.001$

\begin{tabular}{|c|c|c|c|c|}
\hline \multirow{2}{*}{$\frac{\text { Species }}{\text { Amphora sp. }}$} & \multirow{2}{*}{$\begin{array}{c}\text { Source of variation } \\
\text { Control vs. PF, F }\end{array}$} & \multicolumn{2}{|c|}{$\mathbf{P}$} & \multirow{2}{*}{ SNK a posteriori tests of the means } \\
\hline & & 0.400 & N.S. & \\
\hline Chaetoceros sp. & Control vs. PF, F & $\leq 0.001$ & 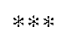 & $\mathrm{PF}>\mathrm{F}=\mathrm{C}$ \\
\hline Entomoneis alata & Control vs. PF, F & 0.495 & N.S. & - \\
\hline Haslea ostrearia & Control vs. PF, F & $\leq 0.001$ & $\approx * *$ & $\mathrm{PH}>\mathrm{H}>\mathrm{C}$ \\
\hline Nitzschia acicularis & Control vs. PF, F & 0.436 & N.S. & - \\
\hline N. closterium & Control vs. PF, F & 0.344 & N.S. & - \\
\hline N. gandersheimiensis & Control vs. PF, F & 0.004 & $* *$ & $\mathrm{PF}=\mathrm{F}>\mathrm{C}$ \\
\hline Skeletonema costatum & Control vs. PF, F & 0.227 & N.S. & $\ldots$ \\
\hline Tetraselmis suecica & Control vs. PF, F & 0.003 & $* *$ & $\mathrm{PF}=\mathrm{F}>\mathrm{C}$ \\
\hline
\end{tabular}

with mucus and secretions from faeces, were analysed and compared with a control. As maximum algal biomasses were reached around the sixth day of growth in the first phase of the experiment, special attention was paid to the amounts of dissolved components measured on the sixth day. Differences in nutrient concentrations were calculated between pseudofaeces and the control and faeces and the control for non-sterile tubes (table III). The tubes with mucus of both pseudofaeces and faeces contained significantly more $\mathrm{PO}_{4}^{3-}$ (t-test, $\left.\mathrm{P} \leq 0.05\right)$ and less $\mathrm{NO}_{3}^{-}+$ $\mathrm{NO}_{2}^{-}$(t-test, $\mathrm{P} \leq 0.01$ ) than the control. For all other nutrients, there was no significant difference (t-test, $\mathrm{P}>0.05$ ).

Nutrient concentrations were also compared after antibiotic treatment. No significant positive differences were found between pseudofaeces, faeces and the control for all dissolved component except $\mathrm{PO}_{4}^{3--}$ which showed a significant increase (t-test, $\mathrm{P} \leq 0.05$ ). Thus, it seems likely that phosphates were mainly released by dissolution of the mucus of both pseudofaeces and faeces. Kaolinite alone released no nutrients by simple dissolution, particularly no silicates (t-test, $\mathrm{P}>0.05$ ).

\section{DISCUSSION}

Our results show that the growth of four microalgae out of nine tested was stimulated when mucus produced by the oyster $C$. gigas was added to the culture medium, which suggests that the mucus contained substances usable by these microalgae for their growth. It is noteworthy that the four microalgae sensitive to the mucus supply belong to all three ecological types tested: benthic with $N$. gandersheimiensis, tychopelagic with $H$. ostrearia, and pelagic with Chaetoceros sp. and T. suecica. Moreover, no trend was noted relative to cell size or taxonomy (one Prasinophyceae and three Diatomophyceae, including two Pennatae and one Centricae). That the biodeposits of $C$. gigas stimulate the growth of some species and not others probably implies quite fundamental differences in biochemistry and physiology between the microalgae tested.

Our results showing that $H$. ostrearia was one of two microalgae with the highest growth response to the mucus of C. gigas confirm the early observations of Ran-

Table III. Differences in nutrient concentrations (all expressed in $\mu \mathrm{mol} \mathrm{L} \mathrm{L}^{-1}$ except carbohydrates in mg $\mathrm{L}^{-1}$ ) calculated between pseudofaeces, faeces and controls at day 6 , with and without antibiotic treatment $+=$ release; $-=$ uptake; ${ }^{*}=\mathrm{P}<0.050 ; * *=\mathrm{P}<0.010$; $* * *=\mathrm{P}<0.001$ (t-test). Values are mean \pm standard error.

\begin{tabular}{lcccc}
\hline & $\begin{array}{c}\text { Pseudofaeces - control } \\
\text { without antibiotic }\end{array}$ & $\begin{array}{c}\text { Faeces - control } \\
\text { without antibiotic }\end{array}$ & $\begin{array}{c}\text { Pseudofacces - control } \\
\text { with antibiotic }\end{array}$ & $\begin{array}{c}\text { Faeces - control } \\
\text { with antibiotic }\end{array}$ \\
\hline $\mathrm{PO}_{4}^{3-}$ & $\pm 0.75^{*} \pm 0.15$ & $\pm 1.00 * * \pm 0.17$ & $\pm 1.19 * \pm 0.03$ & $\pm 1.14 * * * \pm 0.05$ \\
$\mathrm{Dissolved} \mathrm{organic} \mathrm{phosphorus}^{-}$ & $-2.46 \pm 0.37$ & $-1.00 \pm 0.32$ & $+1.42 \pm 0.45$ & $+1.76 \pm 0.51$ \\
$\mathrm{NH}_{4}^{+}$ & $+4.27 \pm 3.03$ & $+0.49 \pm 2.92$ & $+1.48 \pm 2.27$ & $-0.82 \pm 2.57$ \\
$\mathrm{NO}_{3}^{-}+\mathrm{NO}_{2}^{-}$ & $-21 * * \pm 8$ & $-14 * * * \pm 4$ & $-14 \pm 4$ & $-6.1 \pm 2.6$ \\
$\mathrm{Dissolved} \mathrm{organic} \mathrm{nitrogen}_{\mathrm{SiO}}^{-}$ & $-53 \pm 16$ & $-19 \pm 14$ & $+4 \pm 31$ & $+27 \pm 51$ \\
Carbohydrates <3000 Da & $-1.2 \pm 0.9$ & $-0.36 \pm 1.00$ & $-2.57 \pm 0.65$ & $1.20 \pm 0.54$ \\
\hline
\end{tabular}


son [47] who noted a higher growth of $H$. ostrearia in the presence of mucus from $C$. angulata and found that this diatom benefited more than other species of Diatomophyceae. As originally suggested by this author, oyster mucus may play a key role in the greening of oyster ponds [51] by favouring the development of $H$. ostrearia. The stimulating action of mucus produced by other marine molluscs was also inferred by Connor and Quinn [17] and Connor [16] who demonstrated a growth effect in microalgac trapped in the mucus of two limpets, Lottia gigantea and Collisella scabra. These microalgae, like those tested in our study, probably use dissolved components from mucus. Bonin and Maestrini [12] showed that certain microalgae in a rich medium can experience heterotrophic metabolism from dissolved organic components. In Diatomophyceae, facultative heterotrophy was observed, especially in the genera Nitzschia and Amphora [48]. However, in the present study, Amphora sp., as well as two of the three Nitzschia species tested ( $N$. acicularis and $N$. closterium), showed no significant growth when mucus was added to the culture medium. Ranson [47] suggested that $H$. ostrearia may use carbohydrates from oyster mucus, and Rubert [50] showed that this diatom was able to use different sources of dissolved organic nitrogen.

Although the results of algal growth tests suggested that the mucus of $C$. gigas provides a source of nutrients, no information on detailed mucus structure in bivalves was available in the literature to guide our studies of the dissolved components released in biodeposits. For marine molluscs, numerous mucus functions have been reported (for a review see [23]), but few data have concerned mucus structure (and only in gastropods) [20, 22]. In our experiment, mucus was associated with biodeposition. Field studies have shown that the mincralization of biodeposits of different marine species can be rapid [28, 32, 43, 56]. Stuart et al. [56] noted rapid mineralization at $10^{\circ} \mathrm{C}$ maximum during the first three days for biodeposits of the mussel Aulacomya ater. In the present study, it is likely that experimental conditions (six days of incubation at $14{ }^{\circ} \mathrm{C}$ ) favoured the mineralization of mucus by bacteria. Although the production of dissolved components from mucus showed a significant increase for phosphates alone, a similar significant increase was observed in experimental tubes treated with antibiotics. This suggests that the dissolved component may have been released by simple solubilization following active vortexing rather than by bacterial degradation. A similar conclusion was reported by Deslous-Paoli and Jousset [24], for faeces of $C$. gigas fed with natural food. This is also consistent with the observations of Davies et al. [21] who found that the main factor responsible for the degradation of Patella vulgata mucus was the mechanical action of sea water and not microbial breakdown. This may explain why enhancement of algal growth in our study was not systematically higher with faeces, which according to Smaal and Prins [54] contain more bacteria than pseudofaeces (mineralization rates in natural foods were higher for facces than pscudofacces in thcir study). These authors supported this conclusion by the work of Prieur [44] who observed the development of large amounts of bacteria in the gut of bivalves, which were probably excreted with the faeces.

Although statistically significant, this increase in phosphate concentration is difficult to interpret in the light of studies concerning the composition of invertebrate $[1,16$, $20,22,36,37,49$ ] or vertebrate [14] mucus. In all cases, mucus is described as a hydrated gel network characterized by protein-polysaccharide complexes. Although it is known that sugars, as well as serine and threonine, the main amino acids of the protein component [22], can be phosphorylated, phosphates are not described as significant components of mucus as compared to other inorganic salts such as sulphates. A rapid examination of the different phyla indicates that there is no universal structure for mucus secretions $[14,20,37]$. At the level of organisms such as molluscs, variations in mucus chemistry occur in relation to the function associated with this material, e.g. acceptance or rejection of particles in the feeding processes of bivalves [9]. Fluctuations have also been observed according to the physiological energetics of the species [20]. With this complexity in mind, it cannot be excluded that another compound not analysed in this study was responsible for the increase in microalgal biomass and/or that metabolites within the mucus may have inhibited the growth of algal species for which growth was not stimulated. A thorough description of bivalve mucus structure, which was beyond the scope of this work, is required to elucidate its role as a substrate for microorganisms and microalgae.

Although our results show that mucus rejected in biodeposits has a stimulating effect on microphyte biomass, the mean algal biomasses obtained during this study cannot be extrapolated to field situations. The purpose of this study was to use an experimental approach to highlight a process, i.e. mucus as a possible substrate for microalgae. However, the fate of nucus at the ecosystem level needs to be studied. A global assessment of mucus rejected 
through biodeposition could be performed for the Marennes-Oléron Bay (France) to suggest its quantitative importance in a shellfish ecosystem. The malacofauna of this bay is dominated by wild and cultivated oysters (C. gigas). An existing ecophysiological model of $C$. gigas constructed for this estuarine environment allows the quantity of particulate matter rejected by an oyster in pseudofaeces and faeces to be estimated over one year [4]. When simulations are expressed for an individual oyster independently of its weight, these rejects on a yearly average are about $110 \mathrm{mg} \mathrm{h}^{-1}$ for pseudofaeces and $40 \mathrm{mg} \mathrm{h}^{-1}$ for faeces. If it is assumed that an average oyster feeds up to $12 \mathrm{~h}$ a day in this intertidal system, and that the individual mean weight of the 110000 tons of oysters in stock farming is $50 \mathrm{~g}$, this gives yearly amounts of biodeposits of about 1060000 tons for pseudofaeces and 390000 tons for faeces. However, mucus in our study represented $8.3 \%$ and $9.2 \%$ of organic matter per $\mathrm{mg}$ of dry weight of pseudofaeces and faeces respectively, both produced in the presence of inorganic particles alone. Therefore, a rough estimation of the amount of mucus biodeposited annually in the overstocked Marennes-Oléron Bay would be around 125000 tons of organic matter.
In addition to its action on the microalgal biomass, mucus may affect natural environments with high bivalve densities, such as coastal shellfish ecosystems or oyster-ponds, by orienting phytoplanktonic and phytobenthic populations. In fact, the responses recorded in this study were quite different from species to species. Together with the nutrient released by bivalve excretion and the mineralization of their biodeposits, the differential utilization of mucus by microalgae represents another indirect effect which may influence specific diversity. However, the importance of mucus, as compared to other feedback mechanisms, remains to be defined. If the pre- and postingestive selective mechanisms of the bivalve, which also act at the specific level, are added to these processes [13, 53], the set of relationships between bivalves and microalgae becomes increasingly complex and far from a simple prey-predator scheme.

\section{Acknowledgements}

The authors are grateful to P.G. Beninger for helpful comments on the manuscript.

\section{REFERENCES}

[1] Ahn H.Y., Sue L.F., Ma J.K.H., Pinkstaff C.A., Pore R.S., Overman D.O., Malanga C.J., Synthesis and secretion of mucous glycoprotein by the gill of Mytilus edulis, I. Histochemical and chromatographic analysis of [14C] glucosamine bioincorporation, Biochim. Biophys. Acta 966 (1988) $122-132$.

[2] Asmus H., Asmus R.M., Mussel beds: limiting or promoting phytoplankton? J. Exp. Mar. Biol. Ecol. 148 (1991) 215-232.

[3] Asmus H., Asmus R.M., Phytoplankton-Mussel bed interactions in intertidal ecosystems, in: Dame R. (Ed.), Bivalve filters feeders in estuarine and coastal ecosystem processes, NATO ASI Series, Vol. G 33, 1993, pp. 57-84.

[4] Barillé L., Héral M., Barillé-Boyer A.-L., Modélisation de l'écophysiologie de l'huître Crassostrea gigas dans un environnement estuarien, Aquat. Living Resour. 10 (1997) 31-48.

[5] Barillé L., Prou J., Héral M., Razet D., Effects of high natural seston concentrations on the feeding, selection, and absorption of the oyster Crassostrea gigas, J. Exp. Mar. Biol. Ecol. 212 (1997) 149-172.

[6] Bernard F.R., Particle sorting and labial palp function in the Pacific oyster Crassostrea gigas (Thunberg), Biol. Bull. 146 (1974) 1-10.
[7] Beninger P., Dufour S., Mucocyte distribution and relationship to particle transport on the pseudolamellibranch gill of Crassostrea virginica (Bivalvia: Ostreidae), Mar. Ecol. Prog. Ser. 137 (1996) 133-138.

[8] Beninger P., Le Pennec M., Histochemistry of the buccooesophageal glands of Mytilus edulis: the importance of mucus ingestion, J. Mar. Biol. Ass. U.K. 73 (1993) 237-240.

[9] Beninger P.G., St-Jean S.D., The role of mucus in particle processing by suspension-feeding marine bivalves: unifying principles, Mar. Biol. 129 (1997) 389-397.

[10] Beninger P.G., Le Pennec M., Donval A., Mode of particle ingestion in five species of suspension-feeding bivalve molluscs, Mar. Biol. 108 (1991) 255-261.

[11] Beninger P.G., St-Jean S., Poussart Y., Ward J.E., Gill function and mucocyte distribution in: Placopecten magellanicus and Mytilus edulis (Mollusca: Bivalvia): the role of mucus in particle transport, Mar. Ecol. Prog. Ser. 98 (1993) 275-282.

[12] Bonin D.J., Maestrini S.Y., Importance of organic nutrients for phytoplankton growth in natural environments: implications for algal species succession, Can. Bull. Fish. Aquat. Sci. 210 (1981) 279-291.

[13] Bougrier S., Hawkins A.J.S., Héral M., Preingestive selection of different microalgal mixtures in Crassostrea gigas and 
Mytilus edulis, analyzed by flow cytometry, Aquaculture 150 (1997) 123-134.

[14] Chantler E., Ratcliffe N.A., Mucus and related topics. Symposia of the Society for Experimental Biology, $n^{\circ} 43$, Cambridge, The Company of Biologists Ltd., 1989, $470 \mathrm{p}$.

[15] Cloern J.E., Does the benthos control phytoplankton biomass in South San Francisco bay? Mar. Ecol. Prog. Ser. 9 (1982) 191-202.

[16] Connor V.M., The use of mucous trails by intertidal limpets to enhance food resources, Biol. Bull. 171 (1986) 548-564.

[17] Connor V.M., Quinn J.F., Stimulation of food species growth by limpet mucus, Science 225 (1984) 843-844.

[18] Dame R.F., The role of bivalve filter-feeder material fluxes in estuarine ecosystems, in: Dame R. (Ed.), Bivalve filters feeders in estuarine and coastal ecosystem processes, NATO ASI Series, Vol. G 33, 1993, pp. 245-269.

[19] Dankers N., Laane R., A comparison of wet oxidation and loss-on-ignition of organic material in suspended matter, Fnviron. Tech. Lett. 4 (1983) 283-290.

[20] Davies M.S., Jones H.D., Hawkins S.J., Seasonal variation in the composition of pedal mucus from Patella vulgata L., J. Exp. Mar. Biol. Ecol. 144 (1990) 101-112.

[21] Davies M.S., Jones H.D., Hawkins S.J., Physical factors affecting the fate of pedal mucus produced by the common limpet Patella vulgata, J. Mar. Biol. Ass. U.K. 72 (1992) 633-643.

[22] Denny M.W., Molecular biomechanics of molluscan mucus secretions, in: Hochachka P.W. (ed.) The Mollusca, Vol. 1, Metabolic biochemistry and molecular biomechanics, Academic Press, New York, 1983, pp. 431-465.

[23] Denny M.W., Invertebrate mucus secretions: functional alternatives to vertebrate paradigms, in: Chantler E., Ratcliffe N.A. (Eds.), Mucus and related topics, Symposia of the Society for Experimental Biology, $n^{\circ} 43$, Cambridge, The Company of Biologists Ltd., 1989, pp. 337-366.

[24] Desluus-Pauli J.M., Jousset J., Transformation du matériel fécal de Crassostrea gigas : évolution biochimique à court terme, Oceanis 13 (4/5) (1987) 581-584.

[25] De Vries I., Hopstaken C.F., Nutrient cycling and ecosystem behaviour in a salt-water lake, Neth. J. Sea Res. 18 (3/4) (1984) 221-245.

[26] Doering P.H., On the contribution of the benthos to pelagic production, J. Mar. Res. 47 (1989) 371-383.

[27] Dubois M., Gilles K.A., Hamilton J.K., Rebers P.A., Smith F., Colorimetric method for determination of sugars and related substances, Anal. Chem. 28 (3) (1956) 350-356.

[28] Grenz C., Quantification et destinée de la biodéposition en zones de production conchylicole intensive en Méditerrannée, thèse doct., univ. Aix-Marseille-II, 1989, 152 p.

[29] Haure J., Sauriau P.-G., Baud J.-P., Effets du vent sur la remise en suspension particulaire en baie de Bourgneuf : conséquences sur la croissance de Crassostrea gigas, J. Rech. Oceanogr. $21(2 / 3)(1996) 88$.
[30] Haven D.S., Morales-Alamo R., Aspects of biodeposition by oysters and other invertebrate filter feeders, Limnol. Oceanogr. 11 (1966) 487-498.

[31] Hawkins A.J.S., Smith R.F.M., Bayne B.L., Héral M., Novel observations underlying the fast growth of suspension feeding shellfish in turbid environment: Mytilus edulis L., Mar. Ecol. Prog. Ser. 131 (1996) 179-190.

[32] Johannes R.E., Satomi M., Composition and nutritive value of fecal pellets of a marine crustacean, Limnol. Oceanogr. 15 (1970) 191-197.

[33] Jørgensen C.B., Bivalve feeder-feeding: Hydrodynamics, bioenergetics, physiology and ecology, Olsen and Olsen, Fredensborg, Denmark, 1990, $140 \mathrm{p}$.

[34] Kautsky N., Wallentinus I., Nutrient release from a baltic Mytilus-red algal community and its role in benthic and pelagic productivity, Ophelia Suppl. 1 (1980) 17-30.

[35] Lucas A., Bioénergétiques des animaux aquatiques, Masson, Paris, 1993, $179 \mathrm{p}$.

[36] Meikle P., Richards G.N., Yellowlees D., Structural determination of the oligosaccharide side chain from a glycoprotein isolated from the mucus of the coral Acropora formosa, J. Bio. Chem. 262 (35) (1987) 16, 941-16, 947.

[37] Meikle P., Richards G.N., Yellowlees D., Structural investigations on the mucus from six species of coral, Mar. Biol. 99 (1988) 187-193.

[38] Moreau C., Des eaux souterraines salées en baie de Bourgneuf pour la production de microalgues en aquaculture : l'azote ammoniacal, le fer et le manganèse dissous, causes de la variabilité de la fertilité potentielle pour trois diatomées-tests, thèse doct., univ. Nantes, 1996, $276 \mathrm{p}$.

[39] Nelson T.C., The feeding mechanism of the oyster, II. On the gills and palps of Ostrea edulis, Crassostrea virginica and Crassostrea angulata, J. Morph. 107 (1960) 163-191.

[40] Officer C.B., Smayda T.J., Mann R., Benthic filter feeding: a natural eutrophication control, Mar. Ecol. Prog. Ser. 9 (1982) 203-210.

[41] Owen G., Feeding and Digestion in the Bivalvia, in: Wilbur K. M., Yonge C. M. (Eds.), Physiology of mollusca, Vol. 2., Academic Press, New York, 1966, p. 1-15.

[42] Palmer R.E., Williams L.G., Effect of particle concentration on filtration efficiency of the bay scallop Argopecten irradians and the oyster Crassostrea virginica, Ophelia 19 (1980) 163174.

[43] Peduzzi P., Herndl G.J., Role of bacteria in decomposition of faecal pellets egested by epiphyte-grazing gastropod Gibbulla umbilicaris, Mar. Biol. 92 (1986) 417-424.

[44] Prieur D., Experimental studies of trophic relationships between marine bacteria and bivalve molluses, Kiel. Meeresforsch. (Sonderh.) 5' (1981) 376-383.

[45] Prins T.C., Smaal A.C.. The role of the blue mussel Mytilus edulis in the cycling of nutrients in the Oosterschelde estuary (The Netherlands), Hydrobiologia 282/283 (1994) 413-429.

[46] Provasoli L., Media and prospects for the cultivation of marine algae, in: Watanabe A., Hattori A. (Eds.), Cultures and collec- 
tion of algae, Proc. USA, Jpn Conf., Hakone, September 1966, Jpn Soc. Plant Physiol. 1968, 63-75.

[47] Ranson G., L'absorption de matières organiques dissoutes par la surface extérieure du corps chez les animaux aquatiques, Ann. Inst. Océanogr. 4 (1927) 49-174.

[48] Ricard M., Atlas du phytoplancton marin, volume II : Diatomophycées, Éd. CNRS, Paris, 1987, 297 p.

[49] Richards G.N., Meikle P.J., Yellowlees D., Preliminary investigations into the chemical nature of mucus from the staghorn coral (Acropora formosa). Proc. Inaugural Great Barrier Reef Conference (1983) 353-359.

[50] Robert J.-M., Fertilité des eaux des claires ostréicoles et verdissement : utilisation de l'azote par les Diatomophycées dominantes, thèse d'État, univ. Nantes, 1983, 281 p.

[51] Robert J.-M., Greening of oyster ponds by the diatom Haslea ostrearia Bory: a model of the phenomenon, 8th diatom symposium, Paris, 1984, pp. 517-523.

[52] Robert J.-M., Maestrini S.Y., Héral M., Dréno J.-P., Backer L., Enrichissement expérimental d'eaux printanières de claires à huîtres en baie de Bourgneuf (Vendée, France) : augmentation de la biomasse et utilisation des éléments nutritifs par les algues unicellulaires, Hydrobiologia 96 (1982) 53-63.

[53] Shumway S.E., Cucci T.L., Newell R.C., Yentsch C.M., Particle selection, ingestion, and absorption in filter-feeding hivalves, J. Exp. Mar. Biol. Ecol. 91 (1985) 77-92.
[54] Smaal A.C., Prins T.C., The uptake of organic matter and the release of inorganic nutrients by bivalve suspension feeder beds, in: Dame R. (Ed.) Bivalve filters feeders in estuarine and coastal ecosystem processes, NATO ASI Series, Vol. G 33 1993, p. 271-298.

[55] Sornin J.-M., Collos Y., Delmas D., Feuillet-Girard M., Gouleau D., Nitrogenous nutrient transfers in oyster ponds: role of sediment in deferred primary production, Mar. Ecol. Prog. Ser. $68(1990) ! 5-22$

[56] Stuart V., Newell R.C., Lucas M.I., Conversion of kelp debris and faecal material from the mussel Aulacomya ater by marine microorganisms, Mar. Ecol. Prog. Ser. 7 (1982) 47-57.

[57] Vahl O., Efficiency of particle retention in Mytilus edulis L., Ophelia 10 (1972) 17-25.

[58] Vincendeau M.-L., Étude expérimentale de la fertilité des eaux des milieux conchylicoles : influence de l'excrétion des huîtres et des palourdes sur la production des Diatomées dominantes, thèse doct., univ. Paris-VI, 1987, $156 \mathrm{p}$.

[59] Yamamuro M., Koïke I., Nitrogen metabolism of the filter-feeding bivalve Corbicula japonica and its significance in primary production of a brackish lake in Japan, Limnol. Oceanogr. 38 (5) (1993) 997-1007.

[60] Yonge C.M., Structure and physiology of the organs of feeding and digestion in Ostrea edulis. J. Mar. Biol. Ass. U.K. 14 (1926) 295-387 